\section{Autonomy, Subsidiarity, Solidarity: Foundations of Cooperative Federalism}

\section{Hugo Cyr}

"The relationship between democracy and federalism means, for example, that in Canada there may be different and equally legitimate majorities in different provinces and territories and at the federal level. No one majority is more or less "legitimate" than the others as an expression of democratic opinion, although, of course, the consequences will vary with the subject matter. A federal system of government enables different provinces to pursue policies responsive to the particular concerns and interests of people in that province. At the same time, Canada as a whole is also a democratic community in which citizens construct and achieve goals on a national scale through a federal government acting within the limits of its jurisdiction. The function of federalism is to enable citizens to participate concurrently in different collectivities and to pursue goals at both a provincial and a federal level."'

\section{Introduction}

Despite the frequent use of "Canadian Confederation" to refer to the coming together of three British colonies to form the Dominion of Canada in 1867, Canada is not a confederation. And despite the fact that the preamble to the Constitution Act, 1867 refers to Canada as a "Union", it is not a unitary State. ${ }^{2}$ Indeed, the Preamble specifies that it was the colonies' desire "to be federally united". 3 It won't be news to readers that Canada is a federation - not a confederation or a unitary state. However, while this may be common knowledge, what this type of political arrangement entails is often much less understood.

By recognizing that federalism is one of the underlying principles that "inform $[\mathrm{s}]$ and sustain[s] the constitutional text" and that it is one of "the vital unstated assumptions upon which the text is based", 4 the Supreme Court in the Secession Reference invited us to reflect on the unstated architecture of our Constitution. As the Supreme Court recognized, our political and constitutional practice has adhered to an underlying principle of federalism, and it has interpreted the written provisions of the Constitution in this light.",

So what does the constitutional principle of federalism entail? Instead of a detailed set of specific rules, the principle of federalism relies on a series of principles that distinguish federations from other political forms. I propose that three such principles stand out from within our constitutional instruments and jurisprudence: autonomy, subsidiarity and federal solidarity. The combination of these three interrelated constitutional principles forms the normative structure that gives Canadian federalism its internal logic. And it is my contention in this paper, that this internal logic is one of cooperative federalism - a form of federalism which is the natural consequence of the respect for those three constitutional principles. It is these principles that must guide the judiciary when it fulfills its special duty as "guardian of the Constitution", 6 and as such, as guardian of the principle of federalism. Specifically, as interpreters and protectors of the Constitution, it is my view that the Supreme Court of Canada must be guided by an understanding of cooperative federalism which is rooted in the principles of autonomy, subsidiarity and federal 
solidarity, as it rules on division of powers cases.

\section{The normative justification for cooperative federalism}

Indeed, each of the three principles autonomy, subsidiarity and federal solidarity - offers its own normative justification for cooperative federalism. First, cooperative federalism is justified as a means to optimise the constitutionally guaranteed autonomy of each partner in the federation. It does so by optimising the capacity of federal partners to effectively manage complex issues, while, at the same time, protecting their respective exclusive jurisdictions. Second, the constitutional principle of subsidiarity entails that powers were not divided at random between federal partners. Rather, they are distributed according to the principles of proximity (geographical or otherwise) and, in case of incapacity, to a subsidiary institution. A relation of subsidiarity is, among other things, one in which the principal is meant to be assisted or helped by a subsidiary power. It would thus be antithetical to the principle of subsidiarity for a subsidiary agent to seek to hinder the capacity of the principal to achieve its legitimate goals. The principle of subsidiarity thus provides a normative justification for the constitutional requirement of cooperation between central authorities and provinces. Third, despite their respective autonomy, the federal government and the provinces are joined together not only by constitutional rules, but also by a shared citizenry towards whom they have obligations. The nested political identities of the citizenry in a federation are institutionally reflected in the fact that each level of government is separate, yet participate in a common body politic. Thus, partners in a federation cannot treat each other as if they were foreign, independent states whose actions do not have direct consequences on their own citizenry. Hurting federal partners amounts to hurting the shared body politic. The principle of federal solidarity thus creates certain positive duties of assistance, and in prohibitions against imposing certain negative externalities on other federal partners. Cooperative federalism is thus normatively justified by the need for each level of government to protect and promote the interests of a shared citizenry forming a common body politic.

\section{Autonomy}

It is well-established that the central government and provincial governments are autonomous within their own spheres of competence. Provinces are not the mere delegates of the central power - as in a decentralized unitary State. Nor is the central government a mere delegate of the provinces - as in a confederation. But what does it mean for federal partners to be autonomous?

Autonomy, as its etymological roots indicate, refers to the "self" (auto) having its own "law" (nomos). The opposite of autonomy is heteronomy; the subjection to external law, the dependence on external power. The extent of the autonomy of a political community is determined by the extent of its control over its own laws. Partners in a federation are not fully autonomous as they are bound by common rules, constitutional rules, to one another, but they nonetheless all have their own space to make their own laws. Indeed, federal partners are not mere delegates of one another; they all have their own primary, law-making powers attributed to them by the Constitution.

While not explicitly stated in the Constitution Act, 1867, the principle of autonomy is well-established in Canadian constitutional law. The fact that the federal authority was created following an agreement between three British colonies to transfer certain of their powers to a central government - and to divide one of those three colonies in two provinces: Ontario and Québec - does not mean that a mere delegation occurred. Indeed, the creation of the Dominion of Canada was ultimately the product of the Westminster Parliament and whatever political impetus that pushed the colonies to 
form a federation. The central authority thus created was not and is not a mere delegate of the provinces. The language of the Constitution Act, 1867 is clear that the central authority was meant to be autonomous from the provinces.

What was less clear, from a mere reading of the 1867 text was the status of the provinces. However, very early on, in the 1880s, the Privy Council specified that Provinces are neither the mere delegates of the Imperial Parliament, nor of the Dominion. $^{7}$ A few years later, the Privy Council also concluded that LieutenantGovernors are as much the representatives of Her Majesty for provincial purposes as the Governor General is for the Dominion. In 1919, if there were any remaining doubts, Viscount Haldane famously wrote in $R e$ The Initiative and Referendum Act ${ }^{9}$ that

\footnotetext{
The scheme of the Act passed in 1867 was thus, not to weld the Provinces into one, nor to subordinate Provincial Governments to a central authority, but to establish a central government in which these Provinces should be represented, entrusted with exclusive authority only in affairs in which they had a common interest. Subject to this each Province was to retain its independence and autonomy and to be directly under the Crown as its head. Within these limits of area and subjects, its local Legislature, so long as the Imperial Parliament did not repeal its own Act conferring this status, was to be supreme, and had such powers as the Imperial Parliament possessed in the plenitude of its own freedom before it handed them over to the Dominion and the Provinces, in accordance with the scheme of distribution which it enacted in 1867.
}

The fact that Canada has since gained its independence from the United Kingdom has not changed the autonomous nature of provinces. ${ }^{10}$ In short: "[t]he Canadian federation rests on the organizing principle that the orders of government are coordinate and not subordinate one to the other.", 11

\section{1-Negative and positive autonomy}

The importance of maintaining the autonomy of both levels of government has traditionally been reflected in the interpretation of the division of powers. However, what was considered necessary to protect such autonomy evolved over time. Initially, it was thought that to ensure the autonomy of each level of law-maker, the attribution of legislative powers between Parliament and legislatures had to be interpreted according to strict lines of demarcation. The basic idea was that maintaining rigid boundaries between each legislative sphere would protect the autonomy of each level of government. Protecting legislative autonomy thus meant policing the legislative borders against unconstitutional intrusions. This is epitomized by the description of jurisdictions as being "watertight compartments.",

This corresponds to the exclusionary or "negative" function of autonomy. The negative function of autonomy is necessary to negate intrusions, and thus, to protect against heteronomy. "Negative autonomy" is not meant as a pejorative expression. It simply refers to the function of excluding other powers from one's own sphere of competence. Negative autonomy is defensive; it protects the governing self against trespass into its exclusive powers.

However, this model of legislative autonomy was soon understood to be incomplete. While being a useful model to defend against intrusions, the exclusionary function of autonomy may also have the paradoxical effect of limiting the respective autonomy of Parliament and the legislatures. Indeed, boundaries that are too rigid and that do not allow for legislative overlaps, limit the capacity of both legislative levels to adopt statutes to deal effectively with complex issues. In other words, merely focusing on negative autonomy would result in limiting the sphere of action of the autonomous federal partners. 
Thus, the principle of autonomy is not limited to the negative function of protecting normative boundaries. It also entails the "positive" function of empowering the relevant political communities to adopt their own laws, to govern themselves. The positive function of autonomy ensures that the self has the power to govern. The wider the range of possible interventions, the larger the capacity to govern. "Positive autonomy" is thus the enabling function of autonomy. While the negative function of the principle of autonomy protects the "auto", the positive function ensures the capacity of the self to establish its "nomos."

The positive function of autonomy is complementary to its negative function. They are the two sides of a coin; we cannot jettison one without losing the other. Therefore, it is not an either/or proposition. Both are necessary.

The enabling function of autonomy is reflected in courts having developed a set of doctrines to enhance the legislative capacities of Parliament and legislatures. For example, the "double aspect" doctrine provides that "subjects which in one aspect and for one purpose fall within s 92, may in another aspect and for another purpose fall within $\mathrm{s}$ $91^{\prime 13}$ of the Constitution Act, 1867. What will matter first and foremost will be the correspondence of the "pith and substance" of the legislative enactment to a head of legislative powers of the legislative body that adopted it. The "incidental effects" of a statute on legislative matters attributed to the other legislative level will not cause the invalidity of the legislation. ${ }^{14}$

To maximise the positive function of autonomy while simultaneously preserving its negative function, the Supreme Court specified in Bell Canada $v$ Québec (Commission de la santé et de la sécurité du travail), that for the double aspect doctrine to operate, there must be two distinct aspects of the matters in question to be regulated. ${ }^{15}$ Thus, while there may be different aspects to a specific object, each aspect is exclusively attributed to one or the other legislative power.

\section{2 - Privileging positive autonomy}

Privileging one of its functions over the other does not jeopardise the principle of autonomy as long as the privileging does not amount to a negation of the other necessary function. While the two functions of the autonomy principle are carefully preserved, Canadian constitutional law tends to privilege a power-maximising interpretation of the positive function of the autonomy principle. For example, ss 92A, 94A and 95 of the Constitution Act, 1867 explicitly recognize concurrent jurisdiction over non-renewable natural resources, forestry resources and electrical energy, old age pensions, agriculture and immigration. These constitutional provisions thus enable both Parliament and provincial legislatures to adopt statutes over these matters.

Favouring the positive function of the principle of autonomy does not necessarily negate its power-preserving function. Indeed, the range of legislative action of both Parliament and legislatures has generally been increased not by subtracting legislative powers from one to give to the other, but by gradually allowing more overlapping legislation, by limiting the use of the "interjurisdictional immunity" doctrine, ${ }^{16}$ and by adopting a narrow definition of the incompatibility test triggering the federal paramountcy rule. ${ }^{17}$ The range of circumstances where negative autonomy can be used against other legislative powers has been limited, but it has not been eliminated.

However, the Supreme Court has recognized that Parliament and legislatures sometimes need to adopt certain provisions that, in their pith and substance, lie outside of their legislative powers. ${ }^{18}$ This is what has been called the "ancillary powers" doctrine. ${ }^{19}$ Sections of an otherwise valid statute may slightly extend outside the sphere of competence of the legislative body that adopted them if it can be shown that 
they bear a rational and functional connection to the rest of the statute. More serious extrajurisdictional extensions will require a higher degree of integration of the impugned sections into the otherwise valid legislation. Indeed, in such cases of largely overflowing legislative provisions, courts will tend towards validating the impugned provisions only if the latter are shown to be necessary for the effectiveness of the legislative scheme within which they are found. ${ }^{20}$ The ancillary powers doctrine is an extreme case of positive autonomy. Not only is positive autonomy privileged in the rare situations where the doctrine is applied, it actually runs against the negative autonomy of the other jurisdiction.

\section{3 - Encroachments on the negative autonomy of provinces}

It is true that the Constitution does not fully protect provincial autonomy. For example, ss 55,57 and 90 of the Constitution Act, 1867 grant the powers of disallowance and reservation to the Governor General over provincial legislation. However, the Supreme Court noted:

Our political and constitutional practice has adhered to an underlying principle of federalism, and has interpreted the written provisions of the Constitution in this light. For example, although the federal power of disallowance was included in the Constitution Act, 1867, the underlying principle of federalism triumphed early. Many constitutional scholars contend that the federal power of disallowance has been abandoned. ${ }^{21}$

Another example of encroachment on the principle of negative autonomy of provinces can be found in the so-called "national concern" doctrine flowing from Parliament's power to adopt laws for "Peace, Order and Good Government" ((POGG). When applicable, the doctrine transfers to Parliament a matter that was once considered a matter of provincial jurisdiction. Parliament thus gains permanent $^{22}$ plenary powers over that matter. ${ }^{23}$
However, the doctrine has a limited application as it requires that:

[f]or a matter to qualify as a matter of national concern (...) it must have a singleness, distinctiveness and indivisibility that clearly distinguishes it from matters of provincial concern and a scale of impact on provincial jurisdiction that is reconcilable with the fundamental distribution of legislative power under the Constitution. ${ }^{24}$

The doctrine is further qualified by the requirement of the so-called "provincial inability" test:

In determining whether a matter has attained the required degree of singleness, distinctiveness and indivisibility that clearly distinguishes it from matters of provincial concern it is relevant to consider what would be the effect on extra-provincial interests of a provincial failure to deal effectively with the control or regulation of the intra-provincial aspects of the matter. ${ }^{25}$

Parliament's power to gain jurisdiction over works it declares to be for the general advantage of Canada, or two or more provinces, ${ }^{26}$ is another example of encroachment on the negative autonomy of provinces. This is a very exceptional power as it appears to go against the federal principle in itself. Indeed, let's recall that in the Reference re Resolution to Amend the Constitution, a majority of the Supreme Court concluded that there was a constitutional convention requiring a substantial measure of provincial consent to amend the Constitution, and that the reason for that convention was that " $\mathrm{t}]$ he federal principle cannot be reconciled with a state of affairs where the modification of provincial legislative powers could be obtained by the unilateral action of the federal authorities." 27 More recently, the Court declared that " $[\mathrm{t}] \mathrm{he}$ Part $\mathrm{V}$ amending formula reflects the principle that constitutional change that engages provincial interests requires both the consent of Parliament and a significant degree of 
provincial consent." 28 Nevertheless, the declaratory power remains on the books.

S 92(10)(c) declarations were most often made in the late $19^{\text {th }}$ century - when the federal powers of reservation and disallowance were also still in use. Since the 1960 s, they have been used very rarely. ${ }^{29}$ As Peter Hogg suggested, "[i]t appears, however, that the federal government and Parliament are sensitive to the anomalous character of the power and are now inclined to use the power only sparingly." ${ }^{30}$ Referring to the powers of disallowance and reservations, and the declaratory power, La Forest J. in Ontario Hydro wrote that they "faded almost into desuetude when these large constitutional and national tasks [of establishing the authority of the central government and the construction of the intercontinental railway] had been accomplished." 31

Even if it were the case that the federal declaratory power had not fallen into desuetude, the Supreme Court, 20 years ago, limited the scope of this power of "exceptional nature". ${ }^{32}$ Indeed, in Ontario Hydro, a majority of the Supreme Court believed that the declaratory power had to be interpreted narrowly to preserve the principle of federalism. The Court concluded that both the POGG principle and the declaratory power were subject to the "same balancing principles of federalism",33 or at least, "similarly subject to balancing federal principles..." 34 Accordingly, the majority of the Court agreed that "Parliament's jurisdiction over a declared work must be limited so as to respect the powers of the provincial legislatures but consistent with the appropriate recognition of the federal interests involved." 35 Therefore, Parliament's jurisdiction over declared works has to be confined to "the sphere of those of aspects of the work which make the work of federal jurisdiction..., 36

It is entirely possible that the declaratory power of s 92(10)(c) would one day be limited to works that qualify under a test similar to the "provincial inability" criteria used under of the "national concern" doctrine of the POGG. This would be in line with what the Supreme Court recently did in the Reference re Supreme Court Act ${ }^{37}$ with s 101 of the Constitution Act, 1867 (which provides Parliament with the power to legislate to create a General Court of Appeal for Canada). ${ }^{38}$ In light of the Supreme Court's importance in the current constitutional architecture, including its "vital role as an institution forming part of the federal system", it declared that "[t]he unilateral power found in s. 101 of the Constitution Act, 1867 has been overtaken by the Court's evolution in the structure of the Constitution, as recognized in Part V of the Constitution Act, 1982."40

Finally, one last potential source of encroachment on the principle of negative autonomy can be found in the general federal paramountcy rule (and the specific provincial paramountcy rule applicable to old age pensions legislation). ${ }^{41}$ Because of the principle of positive autonomy, Parliament and legislatures have extended legislative powers that may overlap. When overlapping legislations are in conflict, a paramountcy rule is necessary to settle the inconsistency. As we have seen above, the notion of conflict triggering the application of the paramountcy rule is narrowly defined; it only covers situations where the federal and provincial provisions create logical inconsistencies, ${ }^{42}$ or when the operation of the provincial provision would clearly frustrate the intent of the paramount statute. ${ }^{43}$ In general, when there is a conflict, the provincial legislative provision remains valid and applicable, but it is inoperable to the extent of its inconsistency with the federal statute - and no more - thus preserving a maximum amount of positive autonomy for provinces. ${ }^{44}$

\section{4 - Autonomy and cooperative federalism}

Legislative conflicts can, to a large extent, be avoided when there are appropriate consultations, negotiations and, ultimately, 
cooperation between levels of governments. This illustrates the fact that, by creating the possibility of legislative overlaps, the principle of positive autonomy produces the factual conditions necessary for the development of cooperative federalism. ${ }^{45} \mathrm{At}$ the same time, both the principles of negative and positive autonomy provide a first normative justification for cooperative federalism. Indeed, cooperative federalism is a means to optimise respect for the positive autonomy of the central and provincial governments through recognition of their extensive powers to govern their own affairs. Simultaneously, it protects negative autonomy by seeking to avoid a situation where those governments will be bound by external rules. In other words, a first normative justification for cooperative federalism is that it seeks to optimise respect for both principles of autonomy through effective and agreed upon rules and governing mechanisms.

That being the case, how can we make sense of all those encroachments on the principle of negative autonomy of provinces? We can start by pointing out that conflictsolving rules were not chosen arbitrarily; they reflect a sense of how the relatively autonomous political communities embodied in the federal and provincial governments are to relate to one another. The type of rules selected to solve such conflicts reflect an organising principle of our federation: subsidiarity.

\section{Subsidiarity}

Infringements upon the negative autonomy of provinces through the "national concern" doctrine, the federal declaratory power and the general federal paramountcy rule are probably all better understood not as a mere privileging of the positive autonomy of the Parliament, but rather as a consequence of the subsidiarity principle. In other words, the constitutional principles that compose the principle of federalism cannot be read in isolation; each qualifies the others. ${ }^{46}$
The division of powers between the central government and the provinces as articulated in the Constitution, was not randomly devised. Rather, it was meant to reflect the principle of subsidiarity. Justice L'Heureux-Dubé, writing for a majority of the Court in Spraytech explained the principle of subsidiarity as "the proposition that law-making and implementation are often best achieved at a level of government that is not only effective, but also closest to the citizens affected and thus most responsive to their needs, to local distinctiveness, and to population diversity." 47

The Supreme Court recently reminded us of the importance of correctly identifying the purposes of our constitutional structures:

\footnotetext{
The Constitution must be interpreted with a view to discerning the structure of government that it seeks to implement. The assumptions that underlie the text and the manner in which the constitutional provisions are intended to interact with one another must inform our interpretation, understanding, and application of the text. ${ }^{48}$
}

The constitutional importance of the principle of subsidiarity therefore flows from the fact that it provides the teleological explanation of the division powers; it explains why it was done and why it was done the way it was. Indeed, the Supreme Court has recognized that the principle of subsidiarity presided over the initial division of powers between the center and the provinces when, for example, it wrote in the Secession Reference that:

The principle of federalism recognizes the diversity of the component parts of Confederation, and the autonomy of provincial governments to develop their societies within their respective spheres of jurisdiction. The federal structure of our country also facilitates democratic participation by distributing power to the government thought to be most suited to achieving the particular societal objective having regard to this diversity. ${ }^{49}$ 
Or when, in Canadian Western Bank ${ }^{50}$, Binnie and LeBel wrote for the majority of the Court that:

[t]he fundamental objectives of federalism were, and still are, to reconcile unity with diversity, promote democratic participation by reserving meaningful powers to the local or regional level and to foster co-operation among governments and legislatures for the common good.

\section{1 - Proximity and effectiveness}

The principle of subsidiarity basically allowed a division of powers according to the twin criteria of proximity and effectiveness. ${ }^{51}$ Proximity refers here both to physical proximity or "local distinctiveness", and to "population diversity." 52 In other words, the division of powers was meant to protect local needs, identities and social values, while at the same time providing the benefits of a larger political unit - including protection against some potential negative internalities. $^{53}$ A quick look at ss 91-95 powers suffices to convince that those twin criteria presided over the division of powers. Indeed, as Professor Abel noted more than 50 years ago, the "Peace, Order and Good Government of Canada" introductory clause of s 91 and the concluding "Generally all Matters of a merely local or private Nature in the Province" s 92(16) clause "effect a twin grant of residuary power, to the Dominion and to the Provinces." ${ }^{54}$ Matters of "local or private nature" except those of any classes of subjects enumerated in s 91 were assigned exclusively to the provinces. ${ }^{55}$ This was done in recognition of the "diversity and autonomy of provincial governments in developing their societies within their respective spheres of jurisdiction." 56 Matters of "Canadian concern", except those enumerated in s 92, were attributed to Parliament.

The idea behind our division of powers is not that provinces are effective at representing local identities, but that they are ineffective, and that federal authorities are more effective, but do not represent a true political community. Rather, the idea of subsidiarity is that there are matters that are more effectively dealt with locally, ${ }^{57}$ or that should be managed by provinces to adequately protect and allow local identities to flourish. ${ }^{58}$ Other matters may be dealt with federally by reason of "provincial inability" 59 or to protect and promote common Canadian values. $^{60}$

The principle of subsidiarity takes for granted that matters of physical proximity are better dealt with by provinces, but that some matters may not be capable of being effectively managed locally. The latter situation may arise, for example, when, under certain specific conditions, the failure to act of one of the federal partners may jeopardise the situation of others, ${ }^{61}$ or when economies of scale made possible by pooling together resources are necessary for some or all of the partners to adequately tackle an issue. ${ }^{62}$

In fact, some have feared ${ }^{63}$ - for very good reasons ${ }^{64}$ - that while the principle of subsidiarity establishes a presumption in favour of local governance, the use of the effectiveness criteria might have the exact reverse effect: instead of operating downward, the principle of subsidiarity might favour centralisation. This may be true even if we should know by now that centralisation is not necessarily the most effective way to organise certain matters. At any rate, the key to avoiding the misuse of the principle of subsidiarity is to remember that concerns of proximity must come first, and concerns of effectiveness only come second. Indeed, the principle of subsidiarity does not require the allocation of legislative power to the institution that would be the most effective in dealing with a particular matter, it rather means that the most proximate institution must govern the matter unless it is unable to do so.

While the principle of subsidiarity presided over the initial division of powers, it has also been used both explicitly and implicitly by the courts to 
"inform our interpretation, understanding, and application of the [constitutional] text". ${ }^{3}$

\section{2 - Explicit uses of the principle of subsidiarity in the Supreme Court's jurisprudence}

As we have seen earlier, the Supreme Court expressly used the principle of subsidiarity in Spraytech. ${ }^{66}$ In Canadian Western Bank Binnie and LeBel JJ justified the constraints that they imposed on the interjurisdictional immunity doctrine by noting that in the past, it was mostly used in favour of Parliament and that this "asymmetrical effect" could "be seen as undermining the principles of subsidiarity. ${ }^{, 67}$ In Lacombe ${ }^{68}$ Deschamps J, in her dissent, noted that the "principle of subsidiarity ... is a component of our federalism, and increasingly of modern federalism elsewhere in the world" and argued that, when applying the federal paramountcy rule, "[t]he unwritten constitutional principle of federalism and its underlying principles of cooperative federalism and subsidiarity favour a strict definition of the concept of conflict."

In the Reference re Assisted Human Reproduction Act, ${ }^{69}$ the Supreme Court was divided four to four on the proper use of the principle of subsidiarity. McLachlin CJC claimed that while it allowed provinces to complement the Assisted Human Reproduction Act, it did not "preclude Parliament from legislating on the shared subject of health." ${ }^{, 70}$ Indeed, she wrote that "[t]he criminal law power may be invoked where there is a legitimate public health evil, and the exercise of this power is not restricted by concerns of subsidiarity." ${ }^{, 71}$ She summarised her views by stating that the principle of "subsidiarity does not override the division of powers in the Constitution Act, 1867". ${ }^{72}$ LeBel and Deschamps JJ., after concluding that the impugned provisions did not fall under the federal criminal law power, but instead were within provincial jurisdiction, wrote that [i]f any doubt remained, this is where the principle of subsidiarity could apply, not as an independent basis for the distribution of legislative powers, but as an interpretive principle that derives, as this Court has held, from the structure of Canadian federalism and that serves as a basis for connecting provisions with an exclusive legislative power. $^{73}$

Justice Cromwell did not take position on this debate.

\section{3 - Implicit uses of the principle of subsidiarity in the Supreme Court's jurisprudence}

The Supreme Court was implicitly guided by the principle of subsidiarity when it developed both the temporary "emergency", "74 and the permanent "national concern" 75 (or, as I prefer to call it, "Canadian concern") branches of the POGG powers. The same could be said of the federal jurisdiction over the regulation of the general trade and commerce under s 91(2) of the Constitution Act, $1867 .{ }^{77}$ The capacity of the provinces to act within their jurisdictions is presumed, and it is up to Parliament to make the exceptional demonstration otherwise. ${ }^{78}$

In fact, Parliament's legislative competence over the regulation of general trade and commerce relies on a provincial inability test similar to the one used to establish the POGG powers over "Canadian concern". ${ }^{79}$ Among the criteria to examine is whether the "failure to include one or more provinces or localities in the scheme jeopardize its successful operation in other parts of the country." 80 This illustrates the concern that subsidiarity has for the creation of certain negative externalities by the provinces.

However, obviously not all potential negative externalities caused by one province upon others will give rise to a justification for a potential legislative displacement of provincial legislatures by Parliament. Indeed, failure to act on a variety of issues could 
cause negative externalities, but not all such negative externalities are constitutionally problematic. For example, a province may decide to offer significantly fewer social services than its neighbours on the basis of the "small government" mandate it received from its electorate. While this policy decision may cause an influx of residents with special needs to neighbouring provinces offering higher levels of social services, this type of policy choice is expected in a federation where provinces all enjoy a large degree of autonomy in deciding their own priorities and the means to achieve them. Equalization payments, to which federal authorities committed themselves in the Constitution Act, 1982, aim precisely at ensuring provinces the means "to provide reasonably comparable levels of public services at reasonably comparable levels of taxation". 81 Thus, provincial autonomy ensures that provinces may make their own policy choices with regard to public services, and the subsidiarity principle ensures that they enjoy the means to carry out such decisions.

Subsidiarity seems also to have guided the development of the "ancillary powers" doctrine which requires that provisions which only slightly "overflow" from the legislative authority that adopted it must be rationally, functionally integrated into otherwise valid legislation to survive constitutional scrutiny. But the more the challenged provision intrudes on the competency of the other level, the more it will have to meet the test of necessity. ${ }^{82}$ In other words, the more the attack on the negative autonomy of another level of government is serious, the more it has to be justified by necessity.

\section{4 - Subsidiarity and cooperative federalism}

While we have discussed how the subsidiarity principle has been used in the division of powers jurisprudence, it is crucial to recall that it is not simply an analytical tool used to organize the data in an attempt to make sense of the Supreme Court's decisions. Subsidiarity divides powers the way it does because it embodies a particular understanding of the relation that must exist between the different levels of government. Subsidium, the Latin root of the term, historically refers to reserve troops on stand-by to offer help, assistance, relief to the regular troops. ${ }^{83}$ Not only are they not the principal troops, but their existence is meant to assist the regular troops - not to compete against them.

This is why the principle of subsidiarity offers a second normative justification for cooperative federalism: subsidiarity implies that institutions standing in a subsidiarity relation to other institutions are meant to help, to offer assistance, to those other institutions. According to the proximity principle, while Parliament may be the principal agent on certain limited matters, it is the subsidiary agent on most others. This means that the central authorities, as subsidiary agents, must cooperate with provinces to fulfil their true role.

It would thus directly contradict the principle of subsidiarity if Parliament were to act in a way that is not aimed at achieving one of the goals for which it is the principal responsible but rather for the very purpose of hindering the capacity of provinces to achieve their own local goals. Indeed, it is one thing to stop intervening on a matter of one's own jurisdiction, and quite another to actively make it more difficult for the governments to which one serves as a subsidiary, to achieve their goals. For example, Parliament was well within its rights to decide that the federal government would no longer manage and use the data collected from the registration of long guns. However, its decision to refuse to disclose to provinces such data collected in cooperation with them, and to destroy such data ${ }^{84}$ for the very purpose of impeding their capacity to manage their own registry system, ${ }^{85}$ strike as clear violations of the subsidiarity principle. Purposeful nuisance is clearly antithetical to subsidiarity. 
Given that the subsidiarity principle provides the underlying rationale of the initial division of powers, and its subsequent interpretations, it is logical that it imposes limitations on the use of the powers so distributed. This should not be surprising since we have now moved clearly "from a system of parliamentary supremacy to one of constitutional supremacy". 86 This is why the principle of federalism that was once seen as only capable of offering reasons justifying certain constitutional conventions, ${ }^{87}$ now has the full power to impose legal obligations. ${ }^{88}$ Indeed, the Supreme Court in the Secession Reference referred approvingly to the dissent in the Patriation Reference to demonstrate that " $[\mathrm{u}]$ nderlying constitutional principles may in certain circumstances give rise to substantive legal obligations (have "full legal force", as we [the Supreme Court] described it in the Patriation Reference)". 89

A section of a federal statute that, in its pith and substance, is not related to a valid federal purpose but is rather aimed at limiting the capacity of provinces to effectively conduct their own legitimate purposes must be invalid as a violation of the principle of subsidiarity. Creating provincial inabilities simply cannot be a valid federal purpose. As Binnie and LeBel JJ. wrote in Canadian Western Bank, "constitutional doctrine must facilitate, not undermine what this Court has called 'cooperative federalism'." 90 Therefore, the subsidiarity principle, as a second normative justification for cooperative federalism, establishes duties between subsidiary authorities and proximate authorities.

But the federal principle also entails a set of duties binding upon all federal partners, irrespective of the vertical connection that bind together the center to the provinces. Such duties flow from the principle of federal solidarity according to which participants in the federation form a common body politic.

\section{Federal Solidarity}

The constitutional bonds that hold the federation together, that give unity to the whole, are integral parts of each political community involved. Far from being external to them, those bonds are constitutive of the participants in the federation. The different levels of government may each incarnate a different political community, but they rely on a common citizenry. Thus, individuals who are members of each province are equally members of the general political community composed of all individuals within the federation. These two elements are key to distinguishing between federations and other forms of political organizations: federations are composed of distinct and autonomous political communities that are existentially joined through shared internal rules that provide for their nested relationships. Therefore, partners in a federation belong to a common body politic, they do not consider each other as "foreign governments." The principle of federal solidarity is the set of normative consequences that flow from the commitment of federal partners to belong to a common body politic.

\section{1 - Solidarity in federations}

The idea behind the principle of federal solidarity has taken different names in a variety of federations. For example, it has been recognized judicially in Germany ${ }^{91}$ and by Belgium's constitutional drafters ${ }^{92}$ (Belgium) as "federal loyalty". "Loyalty" refers to a set of benevolent attitudes and commitments towards another; it is a disposition to (partially) forgo one's selfinterest in favour of another. This disposition goes beyond "respect". It expresses a sense of belonging to a common order rather than merely sharing a space in that order. For federated states to be "loyal" to one another, or towards the central authority, requires a conciliatory attitude. All this entails a certain benevolence towards the others that is clearly not limited to one's formal obligations. This may, for 
example, be reflected in the compulsion to not only avoid hurting the other - for example, by avoiding causing nasty externalities to be supported by the other but also to positively assist that other. That being said, the term may cause confusion as it may - mistakenly - lead one to consider that its only duty is towards a superior, which is not the sense in which it is used in the federal context. Austrian jurisprudence refers instead to the duty of "mutual consideration". 93 This expression highlights more clearly the element of reciprocity involved. However, it is still not entirely satisfactory as it could be interpreted as merely a matter of fairness when, in fact, it requires, as we have just seen, much more than that. Switzerland's Constitution refers more clearly to duties of "mutual help", "assistance" and "collaboration". 94 The South African Constitution, under the heading "principles of co-operative government and intergovernmental relations," entrenched in the most explicit terms the idea of federal solidarity and what it entails. ${ }^{95}$

By whatever expression we may want to refer to it, the principle of "federal loyalty", "mutual consideration", federal solidarity or other equivalent expressions - is inherent to all federations. ${ }^{96}$ The general idea behind each of these formulations is that governments forming a federation do not merely calculate their actions to be to their own benefit. By forming a federation, partners intend to work collectively for the common good of a shared citizenry. Each government - be it federal, provincial or territorial - owes special duties to the other common members of the federation that they do not necessarily owe to foreign states (or that do not owe with the same degree of intensity) precisely because they belong to a common body politic.

Let's take a first example of such special duties owed to other partners in a federation. In Premier, Western Cape $v$ The President of the Republic of South Africa and Another, the South African Constitutional Court explained that s 41, which provides for the principles of cooperative government and intergovernmental relations, includes "provisions setting common goals for all spheres of government requiring cooperation between them in mutual trust and good faith."97 More specifically, s 41(1)(g) requires that:
All spheres of government and all organs of state within each sphere must . . . exercise their powers and perform their functions in a manner that does not encroach on the geographical, functional or institutional integrity of government in another sphere."

The Court went on to state that:

\begin{abstract}
Although the circumstances in which section $41(1)(\mathrm{g})$ can be invoked to defeat the exercise of a lawful power are not entirely clear, the purpose of the section seems to be to prevent one sphere of government using its powers in ways which would undermine other spheres of government, and prevent them from functioning effectively. ${ }^{98}$
\end{abstract}

Thus, contrary to the principle of subsidiarity, this is not a principle used to allocate powers. It merely serves to qualify their use. Indeed, the Court explicitly writes: "Section 41(1)(g) is concerned with the way power is exercised, not with whether or not a power exists.'

\section{2 - Canadian principle of federal solidarity}

While it is true that the principle of federal solidarity has not yet been explicitly identified by the Supreme Court as being a key component of the principle of federalism, it is nonetheless clearly at work both in our political practices and in a variety of constitutional rules. First, the principle of federal solidarity explains the different rules and practices that ensure that burdens and capacities are cooperatively shared in ways that positively sustain the common body politics. Let's call this the "empowering function" of federal solidarity. Second, the principle of federal solidarity acts to guarantee against abusive actions of 
federal partners towards the other members of the common body politic. Let's call this the "protective function" of federal solidarity. We will briefly examine them in turns.

\section{3 - Empowering function of federal solidarity}

To work towards a common good while acknowledging their respective autonomy, Ottawa and the provinces inform and consult each other, they assist and support one another, they coordinate their actions, collaborate on different project, etc. This can be seen, for example, in times of emergency, such as when a forest fire breaks out and a province needs assistance, or in the everyday course of business of delegated agencies. ${ }^{100}$ The activities of the Council of the Federation (especially its special working groups) offer examples of formal collaboration and exchanges of information, while informal networks between departments also exchange information on a daily basis.

The principle is also reflected in a series of entrenched constitutional rules. Take, for example, the federal commitment to equalization payments provided by s 36 of the Constitution Act, 1982. Or the general obligation to negotiate constitutional changes when one partner in the federation legitimately seeks an amendment to the Constitution. ${ }^{101}$ However, the extent to which federal partners have a constitutional obligation to positively assist and cooperate with others on other matters has not yet been clearly defined by the Canadian jurisprudence. As we are about to see, the Constitution sets up protections against the abuse by one of the federal partners' powers against other members of the common body politic.

\section{4 - Protective function of federal solidarity}

The protective function of federal solidarity guarantees against the imposition of certain negative externalities on other federal partners. The most obvious example is certainly the unconstitutionality of unilateral secession. ${ }^{102}$ In the same spirit, the Supreme Court recently reminded the federal government that Parliament acting alone cannot modify a "core component of the Canadian federal structure of government."

The territoriality principle of provincial legislation, ${ }^{104}$ as well as provincial incapacity to adopt indirect taxation schemes were also aimed at preventing provinces from imposing abusive negative externalities to other provinces. ${ }^{105} \mathrm{~A}$ good illustration of this rationale for the territoriality principle of provincial laws is to be found in Interprovincial Co-operatives Ltd. $v \quad R$ where Pigeon J. wrote "it does not appear to me that a province can validly license on its territory operations having an injurious effect outside its borders so as to afford a defence against whatever remedies are available at common law in favour of persons suffering injury thereby in another province." ${ }^{106}$ Pigeon J. also suggested, in obiter, that the situation would not be different if dams were built in a province and that same province were attempting to licence the flooding of lands in an adjoining province. $^{107}$

In fact, it is precisely in order to ensure that lack of cooperation between provinces would not result on the imposition of abusive negative externalities that many subject-matters were left to the federal Parliament. This is the case, for example, with the regulation of interprovincial trade and commerce, ${ }^{108}$ ferries between provinces, ${ }^{109}$ the interprovincial matters covered by the "Canadian concern" branch of $\mathrm{POGG}^{110}$ and the interprovincial works and undertakings mentioned at s 92(10) of the Constitution Act, 1867. Those matters were attributed to Parliament to ensure solidarity between members of the federation.

Also, the jurisprudence, through the principle of 'comity', has developed a principle very similar to the civil law 
doctrine against "abuse of rights". The civil law doctrine recognized by the Supreme Court in Houle v Canadian National Bank ${ }^{111}$ and codified at art. 7 of the Civil Code of Québec provides that "No right may be exercised with the intent of injuring another or in an excessive and unreasonable manner which is contrary to the requirements of good faith."112 Indeed, it appears to be the very principle that the Supreme Court used in Hunt v. $T \& N$ plc ${ }^{113}$ under the guise of a constitutionally-required principle of 'comity'" The Supreme Court did not deny that a province has the power to enact "legislation that may have some effect on litigation in other provinces"115 or "respecting modalities for recognition of judgments of other provinces"116 under their s 92(13), Constitution Act, 1867. Instead, the Court concluded that it must do so in a way that respects "the minimum standards of order and fairness addressed in Morguard". 117

At first sight, it may appear as if Hunt and Morguard went further than simply imposing limits on the exercise of provincial powers. The doctrine of 'comity' may appear to have been more far reaching than simply imposing limits akin to those that flow from the doctrine against "abuse of rights". The principles of 'comity' seem, indeed, to have limited provincial legislative powers in themselves. La Forest J. wrote for the Court:

In short, to use the expressions employed in Morguard (...), the "integrating character of our constitutional arrangements as they apply to interprovincial mobility" calls for the courts in each province to give "full faith and credit" to the judgments of the courts of sister provinces. This, as also noted in Morguard, is inherent in the structure of the Canadian federation, and, as such, is beyond the power of provincial legislatures to override. $^{118}$

But it is important to note that the provincial statute in question was found "constitutionally inapplicable because it offends against the principles enunciated in Morguard" 119 and that it was thus "unnecessary (...) to consider whether it is wholly unconstitutional because, in pith and substance, it relates to a matter outside the province." 120 In brief, the principle of 'comity' does not invalidate provincial statutes, but springs into action at the applicability stage of analysis.

We need to highlight that the Supreme Court further noted that "notion of comity among independent nation States lacks the constitutional status it enjoys among the provinces of the Canadian federation."121 The principle of comity therefore does not appear as an application of the territoriality principle of provincial laws, but rather as a set of constraints associated with the legitimate exercise of powers within the federation.

It seems that a similar reasoning would apply by reason of the principle of federal solidarity to a federal or a provincial statute adopted "with the intent of injuring another" federal partner, or "in an excessive and unreasonable manner which is contrary to the requirements of good faith." Such a statute might not be invalid, but it could nonetheless be declared inapplicable to the other partners in the federation.

Because Parliament has a special constitutional duty to foster solidarity within the federation, it is especially egregious when it is the one acting against it. It does so when it use its powers not for the purpose of advancing its legitimate objectives, but rather for the very purpose of creating negative externalities to provinces, or when it uses its power in a way that creates abusive negative externalities that run contrary to the requirements of good faith. Parliament's Ending the Long-gun Registry $A c t^{122}$ appears to be a case in point. Federal solidarity may not require that Parliament puts in place a mechanism to share gunrelated data among partners in the federation, and may not even require that the federal government keeps contributing once 
it is in place. Parliament could in fact withdraw its participation from this cooperative mechanism. However, it goes beyond its federal purposes, and against the federal solidarity principle, when it decides to deny access to the data collected in cooperation with provinces and destroys it. While the federal statute should be held to be valid, given the principle of federal solidarity, it should be inapplicable to provinces seeking to access the data that has been cooperatively collected.

\section{5 - Solidarity and cooperative federalism}

While the principle of autonomy protects the distinctiveness of each political community, the principle of federal solidarity provides a third normative justification for cooperative federalism by ensuring that those autonomous political communities treat each other as partners in a common political project. The principle of solidarity, the commitment of federal partners to belong to a common body politic requires that they cooperate with one another. Failure to cooperate, to share the common burdens, endangers the existence of the common body politic. Acting in bad faith towards the other members of the body politic, abusing one's powers to the detriment of one's federal partners, also go against the purposes of forming a common body politic. Indeed, hurting the citizens of a federal partner amounts to directly or indirectly ${ }^{123}$ hurting the citizens of a political body to which one's own citizens also belong.

\section{Conclusion}

In an era where the Supreme Court has moved away from a formalist understanding of the Constitution to a more principlesbased approach, ${ }^{124}$ it has become easier to see the hidden federal structure that underlies our constitutional practices. Taking seriously the constitutional principle of federalism means seriously examining the rationales behind the federal structure of our government. Autonomy aims at achieving the good of self-government - both at the federal and provincial levels. Subsidiarity aims at protection of self-government while ensuring the benefits of effectiveness. Solidarity aims at ensuring that the benefits of diversity will not be gained at the expense of unity. Each of these three constitutional principles offers distinct normative justifications for cooperative federalism. Ultimately, these three principles of federalism are fundamentally important to our constitutional tradition precisely because they are the ones that guarantee the truth of the famous quote from the Secession Reference that was cited at the very beginning of this article. ${ }^{125}$

The principles of autonomy, subsidiarity and federal solidarity are the foundations upon which our federal structure of government has been built. We cannot tamper with them without endangering the stability our constitutional edifice.

\section{Notes}

* Hugo Cyr, LL.B., B.C.L. (McGill), LL.M. (Yale), LL.D. (U. de Montréal). Professor, Director of Graduate Studies in Law, Faculté de science politique et de droit, Université du Québec à Montréal (UQAM). Petra Vrtkova, Léa Brière-Godbout, Étienne Chénier-Laflèche and Issaou Soumanou have provided the author with detailed notes on the concepts of subsidiarity and solidarity in private and public law, domestically and in various other legal systems. He is most indebted to their hard work and valuable assistance. The author would also like to thank the Secrétariat aux affaires intergouvernementales canadiennes (SAIC) for its financial support to his research project on the federal principle. The views expressed here are the author's and do not necessarily reflect those of the SAIC.

1 Reference re Secession of Quebec, [1998] 2 SCR 217, [1998] SCJ No 61 at para 66 [Secession Reference].

2 Constitution Act, 1867 (UK), 30 \& 31 Vict, c 3, preamble, reprinted in RSC 1985, Appendix II, No 5 [CA, 1867].

3 Ibid.

$4 \quad$ Secession Reference, supra note 1 at para 49.

$5 \quad$ Ibid at para 55. 
6 Hunter v. Southam Inc., [1984] 2 S.C.R. 145, at p. 155, per Dickson J. (as he then was).

7 Hodge $v$ R, [1883-84] 9 AC 117 at 132 [Hodge].

$8 \quad$ Liquidators of the Maritime Bank v New Brunswick (Receiver-General), [1892] AC 437 at 443. See also Canada v Carroll, [1948] SCR 126 and King $v$ Carroll, [1950] SCR 73 at 75 where the Supreme Court held that "the office of Lieutenant-Governor is not a public office under His Majesty in respect of His Government of Canada, but that it is a public office In respect of the Government of the Province for which he is appointed".

9 (1919) AC 935 at 942.

10 Lord Atkin wrote that "[w]hile the ship of state now sails on larger ventures and into foreign waters she still retains the watertight compartments which are an essential part of her original structure." Canada $(A G) v$ Ontario (AG), [1937] AC 326 at 354 (PC) [Labour Conventions case].

11 Reference re Securities Act (Canada), 2011 SCC 66, [2011] 3 SCR 837 at para 71

[Reference re Securities Act].

12 The expression comes from Lord Atkin's previously cited phrase from the Labour Conventions case, supra note 11.

13 Hodge, supra note 8 at 130.

14 Canadian Western Bank v Alberta, 2007 SCC 22, [2007] 2 SCR 3 at para 28 [Canadian Western Bank].

15 [1988] 1 SCR 749 at para 299, 2005 Carswell NS 633 at para 260 (WL Can).

16 Canadian Western Bank, supra note 14 at paras 33-68; Quebec (Attorney General) v Canadian Owners and Pilots Association, 2010 SCC 39, [2010] 2 SCR 536 at para 45 [COPA]. In Bank of Montreal v Marcotte, 2014 SCC 55 at para 66 [Marcotte], the Supreme Court apparently required that the provincial statute be such to "impair any activities that are "vital or essential to [the federal activity]" such that Parliament might be forced to specifically legislate to override the provincial law" to be ruled inapplicable.

17 Canadian Western Bank, supra note 14 at paras 73-75; Marcotte, ibid at para 70.

18 General Motors of Canada Ltd v City National Leasing, [1989] 1 SCR 641 at 66870, [1989] SCJ No 28 and Global Securities Corp v British Columbia (Securities Commission), 2000 SCC 21, [2000] 1 SCR 494 at para 45.
19 See also Reference re Goods and Services Tax, [1992] 2 SCR 445; Kitkatla Band v British Columbia (Minister of Small Business, Tourism and Culture), 2002 SCC 31, [2002] 2 SCR 146; Kirkbi AG v Ritvik Holdings Inc, 2005 SCC 65, [2005] 3 SCR 302; Canadian Western Bank, supra note 14; Quebec (Attorney General) v Lacombe, 2010 SCC 38, [2010] 2 SCR 453 [Lacombe].

20 On the varying degrees of required integration, see Lacombe, ibid at paras 32-46.

21 Secession Reference, supra 1 at para 55.

22 Reference re Anti-Inflation Act, [1976] 2 SCR 373 at 444 Beetz J (dissenting, but not on this point) [Reference re Anti-Inflation Act].

$23 R v$ Crown Zellerbach Canada Ltd, [1988] 1 SCR 401 at 433 (Le Dain J, for the majority, adopting the position of Beetz $\mathrm{J}$ (dissenting, but not on this point) in Reference re Anti-Inflation Act, ibid) [Crown Zellerbach].

24 Crown Zellerbach, ibid at 432.

25 Ibid.

$26 C A, 1867$, supra note 2, ss 91(29) and 92(10)(c).

27 Reference re Resolution to Amend the Constitution, [1981] 1 SCR 753 at 905-906 [Patriation Reference].

28 Reference re Senate Reform, 2014 SCC 32 at para 29, 369 DLR (4th) 577 [Reference re Senate Reform]. See also para 34.

29 Peter Hogg, Constitutional Law of Canada. Student Edition 2009 (Scarborough, Thomson Carswell, 2009) §22.8 at 577 [Hogg]. He was only able to identify two cases since 1967.

30 Hogg, ibid, cited with approval by Iacobucci J for Sopinka and Cory JJ (dissenting on the result, but not on this point) in Ontario Hydro $v$ Ontario (Labour Relations Board), [1993] 3 SCR 327 at 401 [Ontario Hydro].

31 Ontario Hydro, ibid at $372 \mathrm{La}$ Forest for L'Heureux-Dubé and Gonthier JJ.

32 Ontario Hydro, ibid 398 Sopinka, Cory and Iacobucci JJ, dissenting on the result. See also La Forest, L'Heureux-Dubé and Gonthier JJ, at 371 , qualifying the declaratory power as "draconian power" and writing that "[t]here is no doubt that the declaratory power is an unusual one that fits uncomfortably in an ideal conceptual view of federalism" (at 370). However, the latter refused to read narrowly the declaratory power "to make it conform to principles of federalism" (at 370), arguing that it was up to political forces that undergird 
federalism and not the judiciary to police the use of that extraordinary power. They argued that "the Constitution must be read as it is, and not in accordance with abstract notions of theorists" (at 370). This type of justification in favour of limiting the Court's intervention seems more consistent with an era of parliamentary supremacy and legal formalism than one of constitutional supremacy where constitutional principles can - and do - impose legal limitations on parliamentary powers. For a recent rejection of an argument that "privileges form over substance", that "reduces the notion of constitutional amendment to a matter of whether or not the letter of the constitutional text is modified" [emphasis added] and that qualifies pure reliance on the text as a "narrow approach" that is "inconsistent with the broad and purposive manner in which the Constitution is understood and interpreted", see Reference re Senate Reform, supra note 28 at para 52.

33 Ontario Hydro, ibid at 423 (Sopinka, Cory and Iacobucci JJ)

34 Ontario Hydro, ibid at 340 (Lamer CJC)

35 Ontario Hydro, ibid at 404 (Sopinka, Cory and Iacobucci JJ) and cited with approval by Lamer $\mathrm{CJC}$ at 340.

36 Ontario Hydro, ibid at 404 (Sopinka, Cory and Iacobucci JJ, dissenting on the result), but with the apparent approval of Lamer CJC on this point at 340. Justice Iacobucci later summarises (at 405): "Parliament's jurisdiction over a declared work is not plenary, but extends only to those aspects of the work which make the work specifically of federal jurisdiction. Put another way, Parliament obtains exclusive jurisdiction to regulate those aspects of the work that are integral to the federal interest in the work."

37 Reference re Supreme Court Act, ss 5 and 6, 2014 SCC 21, [2014] 1 SCR 433 [Reference re Supreme Court Act].

38 CA, 1867, supra note 2, s 101 reads "The Parliament of Canada may, notwithstanding anything in this Act, from Time to Time provide for the Constitution, Maintenance, and Organization of a General Court of Appeal for Canada, and for the Establishment of any additional Courts for the better Administration of the Laws of Canada."

39 Reference re Supreme Court Act, supra note 37 at para 85 .

40 Ibid at para 101 [emphasis added].
41 CA, 1867, supra note 2, s 94A

42 I.e. when it is impossible to respect both norms simultaneously.

43 Law Society of British Columbia v Mangat, 2001 SCC 67 at para 70, [2001] 3 SCR 113; Rothmans, Benson \& Hedges Inc $v$ Saskatchewan, 2005 SCC 13 at para 21, [2005] 1 SCR 188, ; Canadian Western Bank, supra note 14 at para 74; COPA, supra note 16 at para 66; Marcotte, supra note 16 at para 71.

44 It is true that, in principle, the "frustration of legislative intent" criteria could lead to more cases of incompatibility than the "logical inconsistency" criteria. However, the "frustration of legislative intent" criteria should be read as simply a specific case of the "logical inconsistency" criteria that applies when the silence of Parliament was meant to confer a positive right to something. In such cases, a tentative restriction on such a positive right would amount to a logical inconsistency: one cannot have a positive right to $\mathrm{X}$ while simultaneously be prohibited to X. Obviously, for Parliament to be able to attribute positive rights, it must have jurisdiction to do so. For an example of an incomplete federal prohibition that did not amount to granting positive right to the non-prohibited elements, see Ross $v$ Registrar of Motor Vehicles et al, [1975] 1 SCR 5, 42 DLR (3d) 68.

45 Reference re Securities Act, supra note 11 at para 132 (“... we may appropriately note the growing practice of resolving the complex governance problems that arise in federations, not by the bare logic of either/or, but by seeking cooperative solutions that meet the needs of the country as a whole as well as its constituent parts.")

46 Secession Reference, supra note 1 at para 50: "[ $t]$ he individual elements of the Constitution are linked to the others, and must be interpreted by reference to the structure of the Constitution as a whole."

47114957 Canada Ltée (Spraytech, Société d'arrosage) v Hudson (Town), 2001 SCC 40, [2001] 2 SCR 241 at para 3 [Spraytech].

48 Reference re Senate Reform, supra note 28 at para 26.

49 Secession Reference, supra note 1 at para 58 [emphasis added]. See also Dwight Newman, "Changing Division of Powers Doctrine and the Emergent Principle of Subsidiarity" (2011) 74:1 Sask L Rev 21 at 26. 
50 Canadian Western Bank, supra note 14 Binnie and LeBel JJ at para 22. See also Consolidated Fastfrate Inc $v$ Western Canada Council of Teamsters, 2009 SCC 53, [2009] 3 SCR 407 at para 29 Rothstein J, where the Supreme Court referred to its previous decision in Canadian Western Bank, ibid and wrote that

[t] he division of powers in ss. 91 to 95 of the Constitution Act, 1867 form the bedrock of our federal system. They seek to preserve local diversity within the federal nation by conferring "[b]road powers" on provincial legislatures, while at the same time "reserving to Parliament powers better exercised in relation to the country as a whole."

See also Reference re Assisted Human Reproduction Act, 2010 SCC 61, [2010] 3 SCR 457 at para 183 LeBel and Deschamps JJ [Reference re Assisted Human Reproduction Act] wrote concerning the Canadian Western Bank decision:

In their view, the powers assigned in the Constitution Act, 1867 to the provinces on the one hand and the central government on the other are largely consistent with the principle of subsidiarity. According to Professor Hogg, the broad interpretation that the Privy Council and this Court generally gave the provincial jurisdiction over property and civil rights is explained by their acceptance of the principle of subsidiarity [...]. This principle is therefore an important component of Canadian federalism.

51 Spraytech, supra note 47.

$52 \quad$ Ibid at para 3.

53 CA, 1867, supra note 2, s 93(1)-(4) is a prime example of a federal mechanism against negative internalities.

54 AS Abel, "What Peace, Order and Good Government?" (1968) 7 West Ont L Rev 1 at 4.

55 LeBel and Deschamps JJ in Reference re Assisted Human Reproduction Act, supra note 50 at para 262, also said that $C A, 1867$, supra note 2, s 92(13), "[b]ecause of its broad scope, this head of power is often referred to as a partial residual jurisdiction." They said the same about provincial powers over matters of merely local or private nature at para 264.

56 Reference re Securities Act, supra note 11 at para 73.
57 See e.g. CA, 1867, supra note 2, s 92(8) (Municipal Institutions in the Province).

58 See e.g. CA, 1867, supra note 2, s 92(13) (Property and Civil Rights in the Province) and s 93 (Education).

59 See e.g. CA, 1867, supra note 2, s 91(7) (Militia, Military and Naval Service, and Defence).

60 See e.g. CA, 1867, supra note 2, s 91(27) (Criminal law).

61 See Crown Zellerbach, supra note 23 at 432, for the precise circumstances in which this reasoning might apply.

62 See e.g. CA, 1867, supra note 2, ss 91(2A) (Unemployment Insurance) and 94A (Old Age Pensions).

63 Eugénie Brouillet, "Canadian Federalism and the Principle of Subsidiarity: Should We Open Pandora's Box?" (2011) 54 SCLR (2d) 601 at 618 [Brouillet].

64 Jean Leclair, "The Supreme Court of Canada's Understanding of Federalism: Efficiency at the Expense of Diversity" (2003) 28 Queen's LJ 411.

65 Reference re Senate Reform, supra note 28 at para 26.

66 Spraytech, supra note 47.

67 Canadian Western Bank, supra note 14 at para 45.

68 Lacombe, supra note 19 at paras 109, 119.

69 Supra note 50.

$70 \quad$ Ibid at para 72.

71 Ibid.

72 Ibid.

$73 \quad$ Ibid at para 273.

74 Reference re Anti-Inflation Act, supra note 23 at 436-437 Martland, Ritchie and Pigeon JJ: In my opinion such conditions [giving rise to the "emergency powers"] exist where there can be said to be an urgent and critical situation adversely affecting all Canadians and being of such proportions as to transcend the authority vested in the Legislatures of the Provinces and thus presenting an emergency which can only be effectively dealt with by Parliament in the exercise of the powers conferred upon it by s 91 of the British North America Act "to make laws for the peace, order and good government of Canada". The authority of Parliament in this regard is, in my opinion, limited to dealing with critical conditions and the necessity to which they give rise and must perforce be confined to 
legislation of a temporary character [emphasis added].

75 See supra notes 22-25 and accompanying text.

76 The term "national" here is equivocal as it may simultaneously refer to a political identity (i.e. Canadian) as well as the identity of the political unit in question (i.e. Canada). While many Canadians may view Canada as their primary "national" community, others, notably in Quebec, may view their province as embodying their primary "national" community. The use of the expression "national concern" thus creates unnecessary confusion in our multinational federation. I will therefore use the expression "Canadian concern" in the rest of this article.

77 Reference re Securities Act, supra note 11 at paras 71-73.

78 In practice, however, the level of demonstration required has often been problematic. For example, the provincial inability test has most often been assessed in abstracto rather than requiring concrete evidence (see Brouillet, supra note 69 at 620). However, the Supreme Court recently required "evidentiary support" to demonstrate that securities regulation has been transformed to transcend provincial jurisdiction to make it a matter of Canadian concern: see Reference re Securities Act, supra note 11 at paras 115-17. In the case of emergency powers, four judges required a demonstration that there was a rational basis for regarding the legislative measure as "temporarily necessary to meet a situation of $[\ldots]$ crisis imperilling the well-being of the people of Canada as a whole and requiring Parliament's stern intervention in the interests of the country as a whole" (Reference re Anti-Inflation Act, supra note23 at 425 Laskin CJC). Three other judges believed that Parliament must show that it was "motivated by a sense of urgent necessity created by highly exceptional circumstances" and very clear evidence that no such emergency had arisen or no longer existed would be required for the Court to overrule Parliament's decision to act (see Reference re Anti-Inflation Act, supra note 23 at 439 Martland, Ritchie and Pigeon JJ) While the threshold is low, the circumstances anticipated where such emergency powers would apply would normally be very rare.

79 Reference re Securities Act, supra note 11 at paras 80 and 108.

$80 \quad$ Ibid at para 108.
81 Constitution Act 1982 (UK), s 36 (2), being Schedule B to the Canada Act 1982 (UK), 1982, c 11.

82 General Motors of Canada Ltd v City National Leasing, [1989] 1 SCR 641 at 667-70; Global Securities Corp v British Columbia (Securities Commission), [2000] 1 SCR 494 at para 45; Kirkbi AG v Ritvik Holdings Inc, 2005 SCC 65 at paras 20-32, [2005] 3 SCR 302; Reference re Assisted Human Reproduction Act, supra note 50 at para 127 McLachlin CJC and paras 19293 LeBel and Deschamps JJ.

83 Dictionnaire historique de la langue française, vol. 3 (Paris: Dictionnaires Le Robert, 1998) sub verbo "subsidiaire".

84 An Act to amend the Criminal Code and the Firearms Act, SC 2012, c 6, s 29 [Ending the Long-gun Registry Act].

85 See the findings of facts of Marc-Andre Blanchard J, in Québec (Procureur général) c. Canada (Procureur général), 2012 QCCS 4202 at paras 136-139. Justice Blanchard cites statements of different members of the Government, including the Right Honorable Prime Minister Harper and concludes that "the Court cannot ignore the fact that Parliament's avowed intention reveals a harmful intent with respect to all other provincial legislatures" [emphasis added].

86 Secession Reference, supra note 1 at para 72.

87 Patriation Reference supra note 27 at 804-06 Laskin CJC, Dickson, Beetz, Estey, McIntyre, Chouinard and Lamer JJ.

88 Secession Reference, supra note 1 at para 54.

89 Secession Reference, ibid. See Martland and Ritchie JJ, dissenting on the question of the legality of patriation (but part of the majority on the question of constitutional conventions) in the Patriation Reference, supra note 27 at 844 45.

90 Canadian Western Bank, supra note 14 at para 24.

91 For a succinct overview of how the doctrine of bundestreue is applied in Germany, see HansPeter Schneider, "Loyalty - Solidarity Subsidiarity. Three Principles of a Judge Made Federalism in Germany" in Hans-Peter Schneider, Jutta Kramer \& Beniamino Caravita Di Toritto, eds, Judge Made Federalism?: The Role of Courts in Federal Systems, (BadenBaden: Nomos, 2009) at 99. On the principle of "federal loyalty", see Jean-François GaudreaultDesBiens, "Cooperative Federalism in Search 
of a Normative Justification: Considering the Principle of Federal Loyalty" (2014) 23 Forum Constitutional Forum __ and Jean-François Gaudreault-DesBiens, "The Ethos of Canadian Aboriginal Law and the Potential Relevance of Federal Loyalty in a Reconfigured Relationship between Aboriginal and Non-Aboriginal Governments: A Thought Experiment" in Ghislain Otis \& Martin Papillon, eds, Fédéralisme et gouvernance autochtone I Federalism and Aboriginal Governance, (Québec: Presses de l’Université Laval, 2013) at 51.

92 The Belgian Constitution, Art 143(1) explicitly adopted the principle of "federal loyalty" ("Dans l'exercice de leurs compétences respectives, l'État fédéral, les communautés, les régions et la Commission communautaire commune agissent dans le respect de la loyauté fédérale, en vue d'éviter des conflits d'intérêts").

93 See Anna Gamper, "On Loyalty and the (Federal) Constitution" (2010) 4 Vienna Online Journal on International Constitutional Law 157 [Gramper]. For a discussion of how the German and the Austrian principles differ, see András Jakab, "Two Opposing Paradigms of Continental European Constitutional Thinking: Austria and Germany" (2009) 58 ICLQ 933.

94 Constitution fédérale de la Confédération Suisse du 18 avril 1999 s 44:

1 La Confédération et les cantons s'entraident dans l'accomplissement de leurs tâches et collaborent entre eux.

2 Ils se doivent respect et assistance. Ils s'accordent réciproquement l'entraide administrative et l'entraide judiciaire. 3 Les différends entre les cantons ou entre les cantons et la Confédération sont, autant que possible, réglés par la négociation ou par la médiation.

95 Constitution of the Republic of South Africa, 1996, No 108 of 1996, ss 40 and 41. See e.g. Premier, Western Cape $v$ The President of the Republic of South Africa and Another, [1999] ZACC 2, 1999 (3) SA 657 [Premier]; National Gambling Board v Premier of KwaZulu-Natal and Others, [2001] ZACC 8, 2002 (2) BCLR 156; Doctors for Life International v Speaker of the National Assembly and Others, [2006] ZACC 11, 2006 (12) BCLR 1399 (CC at paras 79-85; Member of the Executive Council for Health, KwaZulu-Nata v Premier of KwaZuluNatal,[2002] ZACC 14, 2002 (10) BCLR 1028.
96 Gamper, supra note 98 at 168-70.

97 Premier, supra note 100 at para 56.

98 Ibid at para 58.

99 Ibid at para 57. [emphasis added]. See also Anna Gamper, "On Loyalty and the (Federal) Constitution", supra note 96 at 164-65, 169.

100 PEI Potato Marketing Board v H B Willis Inc, [1952] 2 SCR 392, [1952] 4 DLR 146; Reference re Agricultural Products Marketing Act, [1978] 2 SCR 1198, [1978] SCJ No 58; Peralta v Ontario, [1988] 2 SCR 1045, [1988] SCJ No 92; Fédération des producteurs de volailles du Québec v Pelland, 2005 SCC 20, [2005] 1 SCR 292.

101 Secession Reference, supra note 1 at para 88.

102 Ibid at para 104.

103 Reference re Senate Reform, supra note 28 at para 77.

104 Reference re Upper Churchill Water Rights Reversion Act, 1980, [1984] 1 SCR 297, [1984] SCJ No 16.

105 Gerald V La Forest, The Allocation of Taxing Power under the Canadian Constitution, 2nd ed, Canadian Tax Paper No 65 (Toronto: Canadian Tax Foundation, 1981) at 92; François Chevrette, "Quelques perles de la jurisprudence constitutionnelle: un survol incomplet et dépourvu de méchanceté!" in Brigitte Lefebvre \& Antoine Leduc, eds, Mélanges Pierre Ciotola (Montreal: Thémis, 2012) at 41-60.

106 Interprovincial Co-operative Ltd $v R$, [1976] 1 SCR 477 at 511 Martland, Pigeon and Beetz JJ.

107 Ibid at 112.

108 CA, 1867, supra note 2, s 91(2).

109 CA, 1867, supra note 2, s 91(13).

110 E.g. Crown Zellerbach, supra note 23.

111 Houle v Canadian National Bank, [1990] 3 SCR 122, [1990] SCJ No 120. See also AI Enterprises Ltd v Bram Enterprises Ltd, 2014 SCC 12, [2014] 1 SCR 177 at para 72; St Lawrence Cement Inc v Barrette, 2008 SCC 64 at paras 23-29, [2008] 3 SCR 392,; Lac d'Amiante du Québec Ltée v 2858-0702 Québec Inc, 2001 SCC 51 at para 73, [2001] 2 SCR 743.

112 art $7 \mathrm{CCQ}$.

113 Hunt $v$ T\&N plc, [1993] 4 SCR 289, [1993] SCJ No 125 [Hunt].

114 In Morguard Investments Ltd v De Savoye, [1990] 3 SCR 1077 at 1098, La Forest J wrote that he did "not think it much matters whether one calls these rules of comity or simply relies 
directly on the reasons of justice, necessity and convenience to which I have already adverted".

115 Hunt, supra note 107 at 324 [emphasis added].

116 Ibid.

117 Ibid.

118 Ibid. [emphasis added].

119 Ibid at 331. [emphasis added].

120 Ibid.

121 Society of Composers, Authors and Music Publishers of Canada $v$ Canadian Assn of Internet Providers, 2004 SCC 45 at para 55, [2004] 2 SCR 427 [emphasis added].

122 Ending the Long-gun Registry Act, supra note 84. See also note 85 and accompanying text.

123 When a province or territory hurts the citizen of another province or territory, it simultaneously hurts Canadian citizens.

124 See Reference re Senate Reform, supra note 28 at para 52.

125 See supra note 1 and accompanying citation. 